\title{
Citrus Postharvest Green Mold: Recent Advances in Fungal Pathogenicity and Fruit Resistance
}

\author{
Yulin Cheng ${ }^{1,2, *}$, Yunlong Lin ${ }^{1,2}$, Haohao Cao ${ }^{1,2}$ and Zhengguo $\mathrm{Li}^{1,2, *}$ \\ 1 Key Laboratory of Plant Hormones and Development Regulation of Chongqing, School of Life Sciences, \\ Chongqing University, Chongqing 401331, China; lin_yun_long@163.com (L.Y.); haohaocao@126.com (H.C.) \\ 2 Center of Plant Functional Genomics, Institute of Advanced Interdisciplinary Studies, Chongqing University, \\ Chongqing 401331, China \\ * Correspondence: yulincheng@cqu.edu.cn (Y.C.); zhengguoli@cqu.edu.cn (Z.L.)
}

Received: 8 February 2020; Accepted: 21 March 2020; Published: 23 March 2020

check for updates

\begin{abstract}
As the major postharvest disease of citrus fruit, postharvest green mold is caused by the necrotrophic fungus Penicillium digitatum $(P d)$, which leads to huge economic losses worldwide. Fungicides are still the main method currently used to control postharvest green mold in citrus fruit storage. Investigating molecular mechanisms of plant-pathogen interactions, including pathogenicity and plant resistance, is crucial for developing novel and safer strategies for effectively controlling plant diseases. Despite fruit-pathogen interactions remaining relatively unexplored compared with well-studied leaf-pathogen interactions, progress has occurred in the citrus fruit-Pd interaction in recent years, mainly due to their genome sequencing and establishment or optimization of their genetic transformation systems. Recent advances in $P d$ pathogenicity on citrus fruit and fruit resistance against $P d$ infection are summarized in this review.
\end{abstract}

Keywords: citrus fruit; postharvest disease; Penicillium digitatum; pathogenesis; disease resistance

\section{Introduction}

Citrus is an important fruit crop worldwide, especially in tropical and subtropical regions around the world, and citrus fruit contains many nutritional components beneficial to human health [1]. During the postharvest stage, including handling, shipping, storing, and marketing, fruit is subjected to a series of biotic or abiotic stresses, and fruit decay and risks to food safety caused by postharvest fungal diseases are some of the most serious problems [2]. Green mold and blue mold, caused by Penicillium digitatum $(P d)$ and Penicillium italicum $(P I)$, respectively, are the two most important postharvest diseases in all citrus production areas [3]. Postharvest green mold, which is the main factor resulting in citrus fruit decay, leads to huge economic losses worldwide every year and can account for up to $90 \%$ of the total citrus postharvest losses, especially in arid zones and subtropical climates [4,5]. As the current control method used for other postharvest fungal diseases on fruit, the mass application of fungicides is still the main control of citrus postharvest green mold in citrus fruit storage $[2,6]$. The use of synthetic fungicides has been regarded as the standard procedure for controlling citrus postharvest green mold in many citrus-producing areas for decades [7]. However, fungicide resistance and noticeable health or environmental risks derived from synthetic fungicides are increasingly concerning $[6,8]$. Thus, developing rational alternatives for controlling citrus postharvest green mold is an imperative.

Plant-pathogen interactions, mainly including pathogenicity and plant resistance, are the central issue in plant pathology research because investigating how plants and pathogens recognize each other and differentiate to establish either a successful or an unsuccessful relationship is crucial in this field of investigation [9]. Many studies have been performed to investigate plant-pathogen interactions, 
indicating that plant-pathogen interactions are complex $[10,11]$. By studying the pathogenicity of plant pathogens, two innovative strategies-host-induced gene silencing (HIGS), which is an RNA interference strategy and involves host expression of double-stranded RNA (dsRNA) targeting essential pathogen genes, and spray-induced gene silencing (SIGS), which involves inhibition of plant pathogens through a direct spray of dsRNA targeting essential pathogen genes-have been used to control plant diseases caused by fungal and oomycete pathogens [12]. HIGS of Verticillium dahliae VdH1 in transgenic cotton plants conferred effective resistance to the wilt disease pathogen $V$. dahliae [13], and spraying of long dsRNAs targeting three fungal cytochrome P450 lanosterol C-14 $\alpha$-demethylases significantly improved barley resistance to necrotrophic fungus Fusarium graminearum [14]. By studying plant resistance to pathogens, transgenesis by overexpressing disease resistance genes (R genes) or positive regulators of plant defense and silencing or genome editing of disease susceptibility genes (S genes) has been used to control different plant diseases caused by fungi, bacteria, and viruses $[15,16]$. The revolutionary biotechnology known as genome editing will probably become a standard tool in plant breeding of disease resistant crops in the future [17]. Genome editing of the conserved S gene MLO in different crops, including wheat and tomato, conferred heritable resistance to powdery mildew $[18,19]$. Thus, investigating the molecular mechanisms of plant-pathogen interactions, including pathogenicity and plant resistance, is crucial for developing novel and safer strategies for effectively controlling plant diseases.

Pathogens can infect different plant tissues and the leaf is a major tissue infected by pathogens [20]. Knowledge of plant-pathogen interactions has mainly been obtained from leaf diseases [11,21], and fruit-pathogen interactions remain relatively unexplored compared with the well-studied leaf-pathogen interactions [2]. Nevertheless, the study of fruit-pathogen interactions has gained increased interest and progress has occurred in the understanding of fungal pathogenicity and fruit resistance [2]. In the citrus fruit- $P d$ interaction, $P d$ genome sequencing and establishment of $P d$ genetic transformation system have been completed recently $[5,22,23]$, which have greatly promoted the understanding of $P d$ pathogenicity at molecular levels [24]. The recent genome sequencing of citrus, optimization of the citrus genetic transformation system, and establishment of citrus CRISPR/Cas9 gene editing system [25-28] have promoted the study of citrus disease resistance [26,29].

In this review, we mainly introduce recent advances in fungal pathogenicity and fruit resistance of citrus postharvest green mold, which provide significant insights into fruit-pathogen interactions and is beneficial for developing novel and safer strategies for controlling citrus postharvest green mold.

\section{Infection Characteristics of $P d$ on Citrus Fruit}

\subsection{Infection Process}

As a necrotrophic fungal pathogen, $P d$ infects citrus fruit through a variety of wounds originating from mechanical damage and environmental factors including cold, burn, wind, hail, and insects [30]. $P d$ conidia dispersed by wind or raindrops onto the surface of citrus fruit can germinate to produce germ tubes under suitable conditions. After penetrating into pericarp cells by germ tubes, $P d$ extends into mesocarp cells and gradually invades the adjacent cells [31]. In the later infection process, white mycelia and newly generated grayish conidia are produced on infected citrus fruit, which is considered the typical disease symptom of citrus postharvest green mold [31,32]. Upon Pd infection, citrus fruit initially shows a water logging symptom and is finally rotted because infected pericarp cells and mesocarp cells are plasmolyzed and their inclusions and organelles are coagulated, dark, and digested [31].

\subsection{Influence Factors of Pd Spore Germination}

The germination of conidia is a key step of $P d$ infection on citrus fruit and some factors influencing $P d$ spore germination have been reported. These $P d$ conidia around the wounds of citrus fruit germinate very well but other $P d$ conidia far from these wounds rarely germinate [31], which is probably due 
to the signal stimulation of spore germination from wounds [33]. The volatiles, including limonene, myrcene, $\alpha$-pinene, and $\beta$-pinene, emitted from the ruptured oil glands in wounded peel tissues were proven to promote the germination of $P d$ conidia [34]. The constituents of orange juice, mainly including sugars and organic acids, also stimulate the germination of $P d$ conidia [35].

The effect of water activity $\left(\mathrm{a}_{\mathrm{w}}\right)$ and temperature on the germination of $P d$ conidia was also investigated [36,37]. $P d$ conidia are able to germinate in the temperature range of $4-30^{\circ} \mathrm{C}$ and the optimum temperature for the germination of $P d$ conidia is $25^{\circ} \mathrm{C}$ [36]. In addition, $P d$ conidia are able to germinate in the $a_{w}$ range $0.90-1.00$, and no germination is observed under $0.90 a_{w}[36,37]$.

\subsection{Mycotoxin during Pd Infection}

Mycotoxin is a severe problem for public health and the analysis of potential mycotoxins in fruits infected by postharvest fungal pathogens are important for their quality control and safety [38]. Thermogenic alkaloids, including tryptoquialanine $\mathrm{A}$ and tryptoquialanine $\mathrm{C}$, were detected in citrus fruit infected by $P d$ [38-40]. However, no other mycotoxins have been reported in $P d$ infection on citrus fruit. The genome sequencing of $P d$ indicates the absence of the biosynthesis of patulin, which is a mycotoxin in Penicillium expansum, another postharvest fungal pathogen closely related to $P d[5]$. Clusters of genes (such as $g s f$, avf, and cyp) responsible for the synthesis of important mycotoxins in other fungal species, including griseofulvin, viridicatumtoxin, fumonisin, clavines, aflatoxins, sterigmatocystin, citrinin, ergot alkaloid, lovastatin, and paxilline, are also absent in the $P d$ genome [5], which can explain why these mycotoxins have not been reported in $P d$ infection on citrus fruit.

As other secondary metabolites, many mycotoxins play important roles in fungal pathogenicity [41,42]. The mycotoxin patulin is involved in the pathogenicity of another postharvest fungal pathogen $P$. expansum [43], which implies the putative role of tryptoquialanines in $P d$ pathogenicity. Deleting a tryptoquialanine-production-related gene tqaA in $P d$ resulted in complete loss of tryptoquialanine production but no significant difference was observed in $P d$ virulence between the $\triangle t q a A$ mutant and the wild type strain, suggesting that tryptoquialanines are not involved in $P d$ pathogenicity [44]. Noticeably, tryptoquialanines may be involved in the protection of decayed citrus from insects because tryptoquialanine A shows high insecticide activity for Aedes Aegypti [39].

\section{Pathogenic Mechanisms of $P d$}

The achievement of $P d$ complete genome, which is the first genome sequencing of a phytopathogenic Penicillium species [5], provides an important basis for understanding the pathogenic mechanisms of $P d$. Genome sequencing shows that $P d$ has a much smaller gene content (around $26 \mathrm{Mb}$ ), consistent with a more specialized lifestyle, compared with the closely-related but nonphytopathogenic $P$. chrysogenum [5]. Whole genome variation analysis revealed very high similarity among globally distributed $P d$ isolates, which points to a recent and global expansion of a single lineage in $P d$ [45]. In addition, putative $P d$ pathogenicity-related genes were identified using a subtractive complementary DNA (cDNA) library of $P d$-infected citrus peel tissues and comparison against the available $P d$ genome sequences [7]. Noticeably, a total of 19 important pathogenicity factors that are responsible for $P d$ virulence on citrus fruit and mainly encode transcription factors, cell wall-related enzymes, protein kinases, and transporters (Figure 1) have been identified using Agrobacterium tumefaciens-mediated transformation system of $P d[22,23]$.

\subsection{Transcription Factors in Pd Pathogenicity}

Transcription factors (TFs)-mediated transcriptional regulation plays important roles in fungal pathogenicity, and many pathogenicity-related transcription factors have been reported in a number of plant fungal pathogens [46]. As the fungus-specific transcription factor, Ste12 is the downstream target of the conserved mitogen-activated protein kinase (MAPK) pathway and is required for fungal pathogenicity in different plant pathogenic fungi [47]. The role of Ste12 in $P d$ pathogenicity was also investigated and the $\triangle P d S t e 12$ mutant exhibited reduced fungal growth and disease symptoms 
on citrus fruit $[48,49]$. Further gene expression analysis revealed that several $P d$ genes involved in transport including two ABC transporters (PMR1 and PMR5), six MFS transporters (PdMfs1-6), and a putative sucrose transporter PdSUT1 were up regulated in the $\Delta$ PdSte12 mutant compared with the wild type strain [48]. Among these transporters, PdMfs1, PdMfs2, and PdSUT1 were reported to be required for $P d$ pathogenicity (see Section 3.4). Two sterol demethylase genes, including CYP51 (also known as $P d C Y P 51 A$ ) and $P d C Y P 51 B$, which are essential for ergosterol synthesis in fungal membranes and are known for their involvement in $P d$ resistance to imazalil and other fungicides inhibiting ergosterol synthesis [50], were downregulated in the $\Delta$ PdSte12 mutant [48]. A recent study showed that PdCYP51B also plays a role in Pd pathogenicity (see Section 3.5). Taken together, transcription factor PdSte12 is involved in $P d$ pathogenicity possibly via negative regulation of transporter genes and positive regulation of sterol demethylase genes.

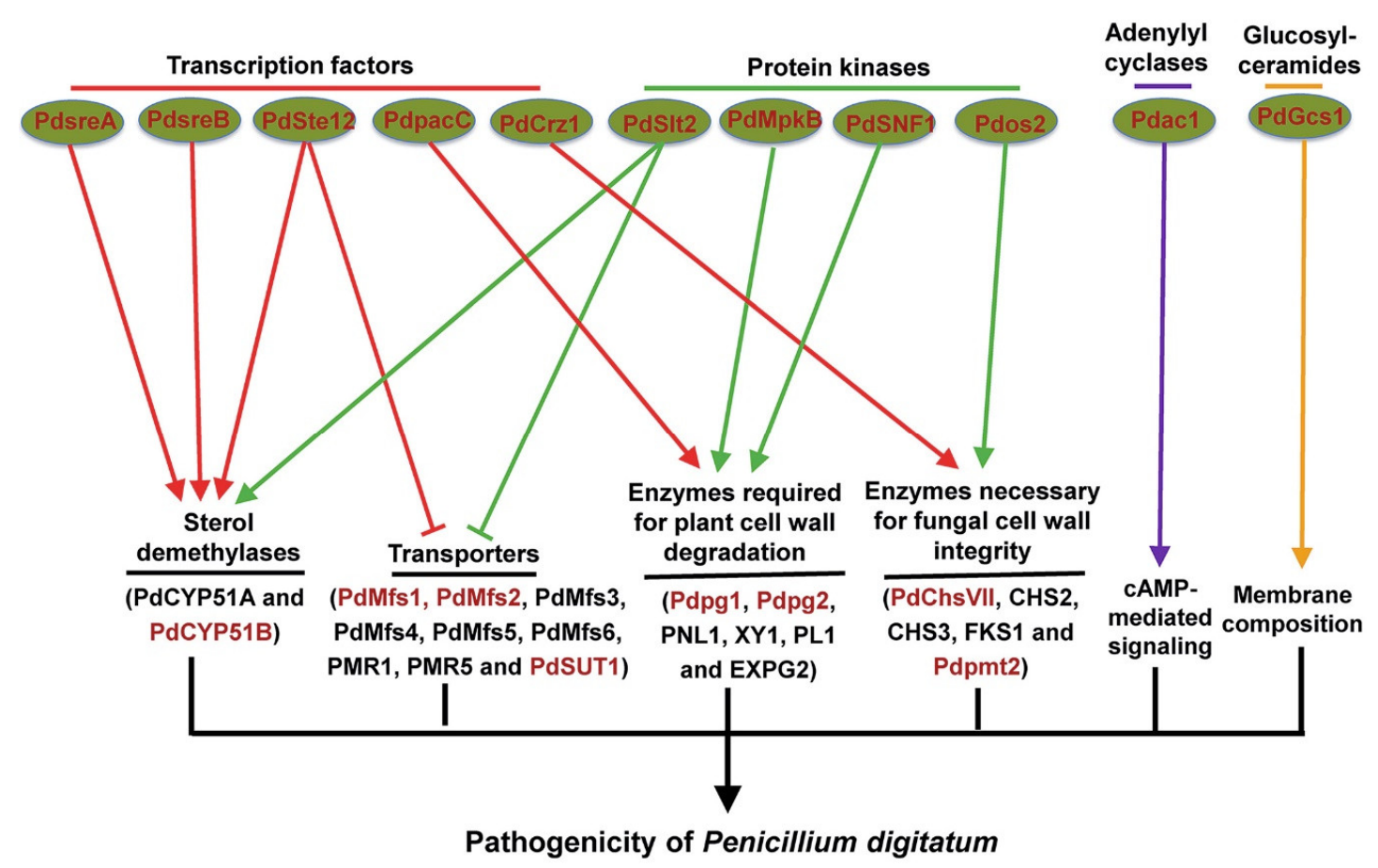

Figure 1. Overview of identified genes (red-colored) involved in the pathogenicity of Penicillium digitatum.

Transcription factor PacC belongs to the conserved PacC/Rim101 signaling cascade to modulate $\mathrm{pH}$ in infection of plant pathogenic fungi [51]. Noticeable $\mathrm{pH}$ differences exist between healthy oranges and $P d$-infected oranges [52], and disruption of $P d p a c C$ resulted in attenuated $P d$ virulence on citrus fruit [53], which indicates that PacC-mediated $\mathrm{pH}$ modulation is also involved in $\mathrm{Pd}$ pathogenicity. Further gene expression analysis showed that two cell wall degrading enzyme genes, including the polygalacturonase Pdpg2 and the pectin lyase Pdpnl1 (also known as PNL1), were upregulated in the wild type strain but not or weakly upregulated in the $\triangle P d p a c C$ mutant upon $P d$ infection [53]. Noticeably, $P d p g 2$ was also reported to be required for $P d$ pathogenicity (see Section 3.2). These results indicate that $\mathrm{PacC}$-mediated $\mathrm{pH}$ modulation of citrus fruit promotes $P d$ infection probably by leading to an optimal $\mathrm{pH}$ for specific cell wall degrading enzymes to degrade citrus peel.

The $\mathrm{Ca}^{2+}$ /calmodulin-dependent pathway plays an important role in fungal pathogenicity [54], and the calcineurin-responsive transcription factor $\mathrm{Crz1}$ is required for virulence of different fungal pathogens, including Botrytis cinerea, Magnaporthe oryzae, and Aspergillus fumigatus [55-57]. The role of Crz1 in $P d$ pathogenicity was investigated and the $\triangle P d C r z 1$ mutant was found to be defective in $P d$ virulence on citrus fruit [58]. Cell wall integrity was defective and three cell wall synthase genes (CHS2, CHS3, and FKS1) were significantly downregulated in the $\triangle P d C r z 1$ mutant compared with the wild type strain [58]. These results indicate that the calcineurin-responsive transcription factor Crz1 is 
involved in $P d$ pathogenicity probably via positive regulation of cell wall synthase genes to maintain the cell wall integrity of $P d$.

Sterol regulatory element binding proteins (SREBPs) are a family of transcription factors that regulate sterol homeostasis in many eukaryotes [59]. SREBP transcription factors play a key role in the regulation for ergosterol biosynthesis in a number of fungal species, and are also required for virulence of several human fungal pathogens including Cryptococcus neoformans and A. fumigatus [60]. However, little is known about the role of SREBP transcription factors in plant fungal pathogens. The putative roles of two SREBP transcription factor encoding genes ( $P d s r e A$ and $P d s r e B)$ in $P d$ pathogenicity were investigated and all mutants including $\triangle P d s r e A, \triangle P d s r e B$, and the double mutant showed reduced ergosterol contents and virulence on citrus fruit [61,62]. In addition, the sterol demethylase gene $P d C Y P 51 B$, which plays a role in $P d$ pathogenicity (see Section 3.5) was downregulated in $\triangle P d s r e A$ and $\triangle P d s r e B$ mutants compared with the wild type strain $[61,62]$. These results indicate that SREBP transcription factors are required for $P d$ pathogenicity possibly via positive regulation of sterol demethylase genes.

\subsection{Cell Wall-Related Enzymes in Pd Pathogenicity}

Cell wall-related enzymes play an important role in plant-pathogen interactions because fungal pathogens invade host tissues by degrading the plant cell wall to obtain nutrients, and cell wall integrity of fungal pathogens is important for protection from host degradation [63,64]. Many Pd genes encoding cell wall-related enzymes, of which cell wall-degrading enzymes are predominant, are significantly upregulated during $P d$ infection on citrus fruit [7], which suggests that cell wall-related enzymes may be involved in $P d$ pathogenicity. Carbohydrate-active enzymes (CAZYmes) are proven to regulate fungal pathogenicity probably by degrading plant cell wall in different phytopathogenic fungi [65]. The role of two major polygalacturonases (PGs), PG1 and PG2, which belong to CAZYmes, in $P d$ pathogenicity was investigated [66]. Both $\triangle P d p g 1$ and $\triangle P d p g 2$ mutants showed reduced disease symptoms on citrus fruit compared with the wild type strain but the defects in the development of green mold and the corresponding galacturonic acid production and tissue softening were more obvious in the $\triangle P d p g 2$ mutant than the $\triangle P d p g 1$ mutant [66]. Since PGs is involved in the degradation of the pectin backbone and pectin is the major component of citrus peel $[53,67]$, these results indicate that plant cell wall degradation enzyme genes $P d p g 1$ and $P d p g 2$ are involved in $P d$ pathogenicity probably via degradation of pectin from citrus peel [66].

Two genes encoding enzymes necessary for fungal cell wall integrity were also reported to regulate $P d$ pathogenicity [68-70]. Several chitin synthase genes were found to be upregulated during $P d$ infection of citrus fruit and one chitin synthase mutant $\triangle P d C h s V I I$ was defective in $P d$ cell wall integrity and virulence on citrus fruit $[68,69]$. Since chitin is an essential component of the fungal cell wall but is not present in plants [71], chitin can be considered an important target for developing new antifungal drugs for controlling citrus postharvest green mold. Protein O-mannosyltransferases (Pmts) catalyze the first step in protein O-mannosylation, which is essential for protein modification and is involved in cell wall synthesis [72]. A gene Pdpmt2 encoding O-mannosyltransferase was proven to regulate $P d$ cell wall integrity and pathogenicity because the $\Delta P d p m t 2$ mutant was defective in cell wall integrity and disease symptoms on citrus fruit [70]. These results highlight the involvement of fungal cell wall integrity in $P d$ pathogenicity.

\subsection{Protein Kinases in Pd Pathogenicity}

Protein kinases (PKs) catalyze the reversible phosphorylation of proteins and the role of PKs in fungal pathogenicity has been investigated during the last two decades [73]. Mitogen-activated protein kinase (MAPK) and cyclic adenosine monophosphate (cAMP)-protein kinase A(PKA) are two conserved and well-studied PK cascades proven to regulate fungal pathogenicity [73]. MAPK-mediated signaling pathways are highly conserved in all eukaryotic organisms, and filamentous fungi have three MAPKs orthologous including Hog1, Slt2, and Fus3/Kss1MAPKs [74]. The Hog1, Slt2, and MAPKs orthologous 
in $P d$, termed Pdos2, PdSlt2, and PdMpkB, were identified and their roles in $P d$ pathogenicity were investigated [75-77]. Compared with the wild type strain, all $\triangle P d o s 2, \triangle P d S l t 2$, and $\triangle P d M p k B$ mutants showed reduced virulence on citrus fruit and even the $\triangle P d M p k B$ mutant failed to induce green mold decay on citrus fruit [75-77]. Although all the three protein kinases are involved in $P d$ pathogenicity, they probably function in different ways. Cell wall integrity of $P d$ is defective in the $\Delta P d o s 2$ mutant [77], which indicates that Pdos2 is involved in $P d$ pathogenicity possibly by maintaining cell wall integrity. Transporter genes (PdMfs1-6, PMR1, and PMR5) and sterol demethylase genes (PdCYP51A and $P d C Y P 51 B)$ are upregulated and downregulated, respectively, in the $\triangle P d S l t 2$ mutant [76], which is similar as $\triangle P d S t e 12$ mutant (see Section 3.1). Thus, PdSlt2 is involved in $P d$ pathogenicity probably via negative regulation of transporters and positive regulation of sterol demethylases. Several genes encoding cell wall-degrading enzymes, such as cutinase, pectin lyase, and rhamnogalacturonan acetylesterase are significantly downregulated in the $\triangle P d M p k B$ mutant [75], suggesting that PdMpkB is involved in $P d$ pathogenicity probably via positive regulation of cell wall-degrading enzymes.

In addition to these conserved PK signaling networks, new PKs related to fungal pathogenicity were identified in recent years [73]. The role of sucrose nonfermenting protein (SNF1p), which belongs to serine/threonine protein kinases and controls carbon source use in microorganisms, in $P d$ pathogenicity was reported [78]. The $\triangle P d S N F 1$ mutant showed reduced disease symptoms and the expression levels of several cell wall-degrading enzyme genes, including pectin lyase 1(PNL1), xylanase 1 (XY1), pectate lyase 1 (PL1), and exo-polygalacturonase 2 (EXPG2), are upregulated in the wild type strain but not in the $\triangle P d S N F 1$ mutant [78], which indicates that PdSNF1 is involved in $P d$ pathogenicity probably via positive regulation of cell wall-degrading enzymes.

\subsection{Transporters in Pd Pathogenicity}

Fungal transporters, mainly including ATP-binding cassette $(\mathrm{ABC})$ transporters and the major facilitator superfamily (MFS) transporters, are known for their involvement in fungicide resistance by promoting the efflux of toxic compounds [79]. Two ABC transporters (PMR1 and PMR5) and two MFS transporters (PdMfs1 and PdMfs2) were proven to regulate $P d$ fungicide resistance [80-84]. PdMfs1 and PdMfs 2 are also involved in $P d$ pathogenicity because both $\Delta P d m f s 1$ and $\Delta P d m f s 2$ mutants are defective in $P d$ virulence on citrus fruit compared with the wild type strain $[80,81]$. Other MFS transporters, including Cfp in Cercospora kikuchii, Ctb4 in C. nicotianae, and ToxA in C. carbonum, were also proven to regulate fungal pathogenicity by secreting toxins because disruption of these MFS genes greatly reduces the accumulation of related toxins and results in attenuated virulence [85-87]. Whether PdMfs1 and PdMfs2 also regulate $P d$ pathogenicity by secreting toxins, such as tryptoquialanine A and tryptoquialanine $C$ [38], remains to be investigated.

In addition to the two major facilitator superfamily transporters PdMfs1 and PdMfs2, a putative sucrose transporter PdSUT1 is involved in Pd pathogenicity, which is proven by the $\triangle P d S U T 1$ mutant showing reduced $P d$ virulence on citrus fruit compared with the wild type strain [88]. Since fungal sucrose transporter is a homologue to plant sucrose transporters [89], and sucrose is induced in citrus fruit upon $P d$ infection [90], we infer that PdSUT1 is involved in $P d$ pathogenicity possibly by transporting sucrose from host citrus fruit to promote $P d$ development.

\subsection{Other Genes in Pd Pathogenicity}

Glucosylceramides (GlcCers) are important compositions of membrane lipids in fungi and a gene encoding GlcCer synthase, $P d G c s 1$, was proven to regulate $P d$ pathogenicity [91]. The complete loss of production of GlcCers (d18:1/18:0 and d18:2/18:0 h) and a decrease in fungal growth and virulence on citrus fruit were observed in the $\triangle P d G c s 1$ mutant compared with the wild type strain [91], indicating that PdGcs1 is involved in $P d$ pathogenicity probably by controlling the biosynthesis of GlcCers in fungal membrane compositions. Since GlcCers are conserved pathogenicity factors in different fungal pathogens and the structure of fungal GlcCers are remarkably distinct from their counterparts in animal cells, fungal GlcCers are ideal targets for new drugs to control fungal diseases [92]. The camelid single 
domain antibodies (VHHs) generated against fungal GlcCers were reported to inhibit the growth of $B$. cinerea in vitro and the final disease symptom on tomato leaves [93]. Whether VHHs can also inhibit $P d$ growth and virulence to finally control citrus postharvest green mold remains to be investigated.

Adenylyl cyclase converts ATP to form cAMP in the conserved cAMP-PKA signaling cascade, [94], and an adenylyl cyclase gene $P d a c 1$ was identified in $P d$ [95]. Pdac1 is required for cAMP production and $P d$ pathogenicity because the $\triangle P d a c 1$ mutant showed decreased accumulation of cAMP and reduced virulence on citrus fruit compared with the wild type strain [95]. These results highlight the involvement of cAMP-mediated signaling in the pathogenicity of postharvest pathogens.

Fungal CYP51s belong to the cytochrome P450 monooxygenase (CYP) superfamily and are essential for ergosterol synthesis in fungal membranes [96]. Fungal CYP51s, such as PdCYP51A and $P d C Y P 51 B$ from $P d$, are known for their involvement in resistance to fungicides inhibiting ergosterol synthesis, but increasing evidence shows that some of them also play a role in fungal growth and virulence [96]. A recent study showed that overexpression of $P d C Y P 51 B$ increased $P d$ virulence on citrus fruit compared with the wild type strain, indicating that PdCYP51B contributes to $P d$ pathogenicity possibly by regulating ergosterol synthesis in $P d$ membranes [97]. Noticeably, $P d C Y P 51 B$ was reported to be positively modulated by other $P d$ pathogenicity factors including transcription factors PdSte12 [48], PdsreA [61], and PdsreB [62], and protein kinase PdSlt2 [76], suggesting that PdCYP51B may be a conserved downstream target in $P d$ pathogenicity.

\section{Fruit Resistance against $P d$ Infection}

Compared with $P d$ pathogenicity, the understanding of fruit resistance against $P d$ infection has lagged. $P d$ can infect nearly all citrus cultivars and no true resistant citrus cultivars exist that show immunity to postharvest green mold, although aggressiveness of postharvest green mold including lesions and incidence varies significantly in different citrus cultivars [34,98]. Upon $P d$ infection, immature citrus fruit shows a lower lesion diameter than commercial and over-mature harvests citrus fruit [99], which indicates that fruit maturity plays an important role in the development of postharvest green mold similar to other postharvest fungal diseases [2]. In addition to intrinsic fruit maturity, several fruit resistance responses, including reactive oxygen species, nitric oxide, secondary metabolites, and primary metabolites, were identified in the citrus fruit- $P d$ interaction (Figure 2).

\subsection{Reactive Oxygen Species and Nitric Oxide in Citrus Fruit Resistance}

Reactive oxygen species (ROS) and nitric oxide (NO) are two important and closely connected signaling molecules in the plant response to biotic stresses [100]. The production of ROS, mainly including hydrogen peroxide $\left(\mathrm{H}_{2} \mathrm{O}_{2}\right)$ and superoxide anion $\left(\mathrm{O}_{2}{ }^{-}\right)$via consumption of oxygen in an oxidative burst, plays an important role in the plant response to pathogen infection, usually during the early infection of pathogens [101]. The role of ROS in leaf disease resistance has been well documented and ROS are involved in leaf disease resistance mainly by inducing the hypersensitive response (HR), which is associated with restricted pathogen growth, causing strengthening of host cell walls via cross-linking of glycoproteins, and activating defense related genes [101]. However, little is known about the role of ROS in fruit resistance to postharvest pathogens [2]. $\mathrm{An}_{2} \mathrm{H}_{2}$ burst occurs in citrus fruit during early $P d$ infection, and exogenous $\mathrm{H}_{2} \mathrm{O}_{2}$ treatment of citrus fruit increases the resistance of citrus fruit against $P d$ infection [4,32]. $\mathrm{H}_{2} \mathrm{O}_{2}$ content and resistance to $P d$ in citrus fruit decline after treatment with the antioxidant melatonin [32]. Further transcriptome analysis showed that cell wall encoding genes and defense related genes are significantly upregulated and downregulated, respectively, upon on melatonin treatment [32]. These results indicate that ROS is involved in citrus fruit resistance against $P d$ infection probably via cell wall strengthening and defense gene activation.

As a diatomic free radical gas, $\mathrm{NO}$ is emerging as a key regulator of diverse plant cellular processes that can interact with other signaling molecules such as $\mathrm{H}_{2} \mathrm{O}_{2}$ in plant resistance $[100,102,103]$. A nitrosative also occurs, resulting in the synthesis of $\mathrm{NO}$ in the plant response to pathogens, usually during the early pathogen infection [104]. Upon exogenous NO treatment, the resistance of citrus 
fruit against the postharvest fungal pathogen Colletotrichum gloeosporioides was enhanced along with increased $\mathrm{H}_{2} \mathrm{O}_{2}$ accumulation [105]. Exogenous $\mathrm{NO}$ treatment can also enhance the resistance of other fruits including tomato and peach against postharvest pathogens [106-109]. Noticeably, exogenous NO improved the resistance of peach fruit to postharvest pathogen Monilinia fructicola by activating the phenylpropanoid pathway [106], which plays an important role in plant disease resistance and was reported to regulate citrus fruit resistance against $P d$ infection (see Section 4.2). The role of NO in citrus fruit resistance against $P d$ infection was investigated preliminarily and exogenous NO treatment enhanced postharvest disease resistance in citrus fruit to $P d$ [110]. This increasing evidence highlights the involvement of $\mathrm{NO}$ in fruit resistance to postharvest pathogens; the detailed function mechanism of $\mathrm{NO}$ in citrus fruit resistance against $P d$ infection remains to be investigated in the future.

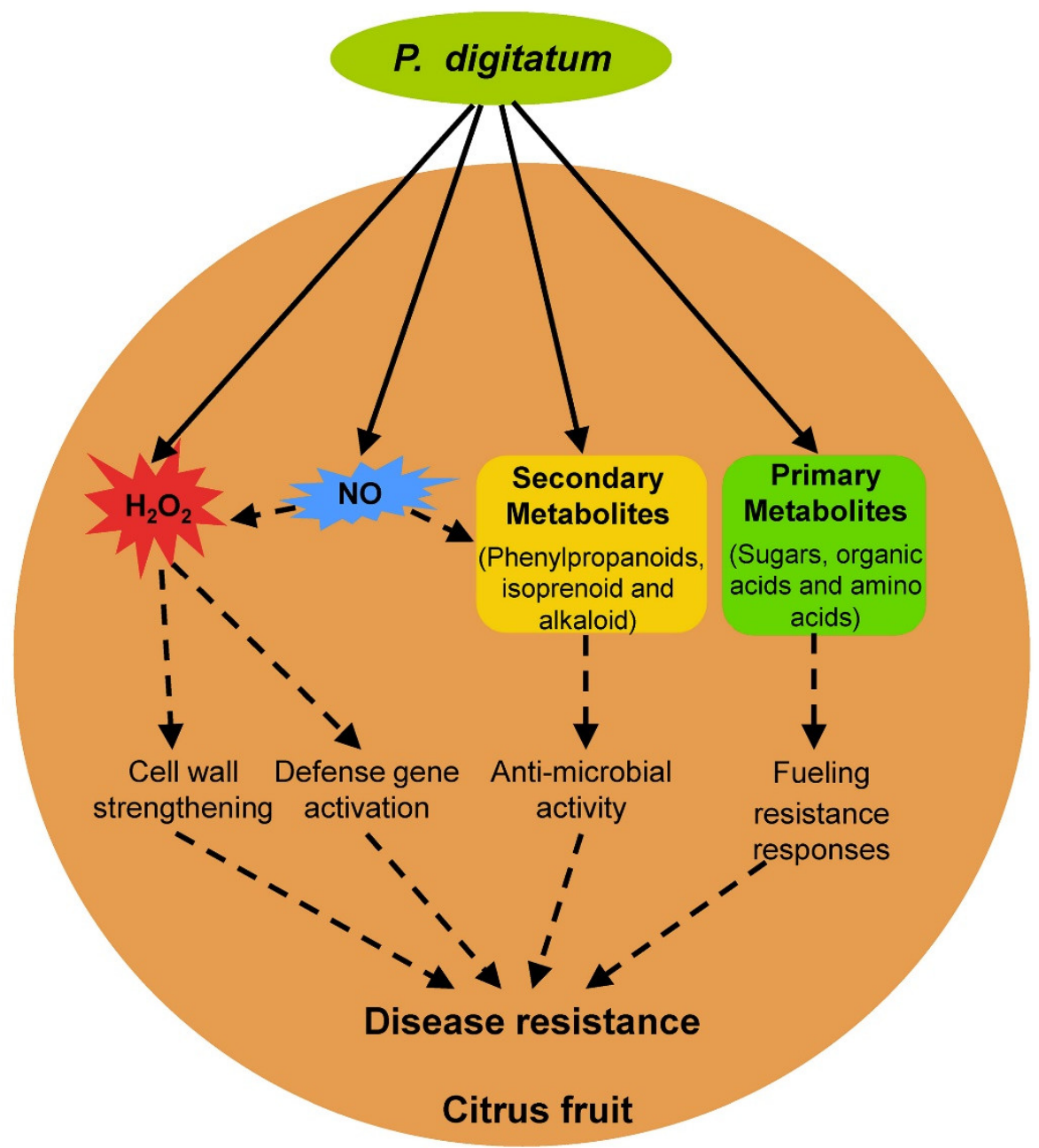

Figure 2. Overview of resistance responses in citrus fruit against Penicillium digitatum infection. Solid and dotted arrows indicate direct and tentative stimulatory modification, respectively.

\subsection{Plant Metabolism in Citrus Fruit Resistance}

Different from primary metabolites, secondary metabolites produced by plants are primarily involved plant defense against herbivores and microbes [111]. Metabolic analysis showed that flavanones, flavones, polymethoxylated flavones, and scoparone are induced in citrus fruit upon $P d$ infection [112]. Transcriptional expression analysis showed that many phenylpropanoid biosynthetic genes are induced in citrus fruit upon $P d$ infection $[112,113] . P d$ infection also induces the expression of citrus genes involved in other secondary metabolisms, including isoprenoid, alkaloid, caffeine synthase, tropinone reductase, and berberine bridge-like [113]. Phenylpropanoids belong to the largest 
group of secondary metabolites produced by plants and are involved in plant disease resistance mainly by acting as phytoalexins with anti-microbial activity [114]. Treatment with phenylpropanoids or their derivatives improved the resistance of citrus fruit to $P d$ [115]. These results highlight the involvement of secondary metabolism in citrus fruit resistance to $P d$.

Increasing evidence indicates that primary metabolism in ATP generation is also involved in plant disease resistance [116,117]. Energy plays a critical role in the execution of plant defense responses due to the expression of many genes from multiple defense pathways, and the main role of primary metabolites in plant disease resistance is fueling defense responses as an energy provider [116,117]. Many genes involved in primary metabolic pathways, such as the citrate cycle (TCA cycle), glycolysis/gluconeogenesis, and biosynthesis of amino acids, are significantly upregulated in plant resistance to different pathogens [118]. To meet the increased demand for carbon in many defense responses, such as the induction of antimicrobial phenylpropanoids, the plant shunts amino acids into energy-generating pathways such as the TCA cycle [116]. The increase in carbohydrates is observed in plant resistance to several different pathogens [116]; floating with glucose, fructose, and sucrose solutions induced several tobacco defense-related genes [119]. However, little is known about primary metabolites in fruit disease resistance compared with leaf disease resistance. Exogenous ATP treatment maintained higher energy levels of harvested litchi fruit and increased fruit resistance to Peronophythora itchii [120], which highlights the role of energy metabolism in fruit response to postharvest pathogen infection. Metabolomic profiling of citrus fruit with enhancement of disease resistance by postharvest heat treatment (HT) showed that HT induced the accumulation of sugars [121]. There was a significant change (upregulated predominantly) in primary metabolites including sugars, organic acids, and amino acids in citrus fruit upon $P d$ infection [90]. These results indicate that primary metabolites are probably also involved in citrus fruit resistance against $P d$ infection by fueling resistance responses.

\subsection{Resistance Mediated by Other Fruits}

Although considered an important postharvest pathogen, $P d$ was previously described to show a limited host range and infect fruits belonging to the Rutaceae family exclusively $[5,122,123]$. However, increasing evidence shows that $P d$ is also an opportunistic pathogen of pome fruits (apple and pear) and stone fruits (nectarine and plum) [124,125], which were previously thought to be nonhosts of $P d$ [126]. Fruit ripeness and postharvest storage significantly impact the infection and colonization of $P d$ in these pome and stone fruits [126-128]. Upon $P d$ inoculation, immature apple fruit showed no decay symptoms, but a small number of apple fruit from commercial harvest showed a decay limited to the initial infection site and over-mature apple fruit developed a complete rot similar with the well-known host citrus fruit [126]. Lignin content and $\mathrm{H}_{2} \mathrm{O}_{2}$ production were highest in immature apple fruit $[126,129]$, which reveals the involvement of lignification and $\mathrm{H}_{2} \mathrm{O}_{2}$ in apple fruit resistance to $P d$. Transcriptomic profiling of apple fruit in response to $P d$ infection showed that apple phenylpropanoid metabolism-related genes are significantly upregulated [130], which is similar as transcriptomic profiling of citrus fruit in response to $P d$ infection [112,113]. Proteome analysis and protein carbonyls (oxi-proteome) analysis formed by ROS revealed that the oxidation of proteins related to energy metabolism and the prevention of free nutrient movement are involved in apple resistance against $P d$ infection [131].

\section{Open Questions}

\subsection{What Are the Roles of Virulence-Associated Effectors in Pd Pathogenicity?}

About 9000 genes exist in the $P d$ genome [5]; thus, identification and functional analysis of more pathogenicity-related $P d$ genes will further reveal $P d$ pathogenicity at the molecular level. Virulence-associated effectors, which are secreted by pathogens to modulate host defense responses or cell physiology to promote plant susceptibility $[132,133]$, are especially worthy of attention in $P d$. Since 
effectors are important pathogenicity factors of plant pathogens and play a key role in plant-pathogen interactions [134], effector biology is a research hotspot, with many pathogenic fungi receiving considerable attention [133]. Effectors can be used to evaluate pathogen evolution and prevalence and be engineered to develop plant disease resistant crops [135]. HIGS of virulence-associated effector PstGSRE1 in transgenic wheat plants significantly improved wheat resistance to the stripe rust pathogen Puccinia striiformis f. sp. tritici, one of the most important fungal pathogens in wheat [136]. However, little is currently known about effectors in postharvest fungal pathogens [2]. There are 552 secreted protein encoding genes in the $P d$ genome and some of them encode putative small cysteine-rich proteins (CRPs) such as effectors or homologous to effector proteins from other pathogenic fungi [5]. Some secreted protein encoding genes were proven to be putative pathogenicity-related genes of $P d$ because their expressions are induced during $P d$ infection on citrus fruit [7]. Functional analysis of these putative effectors in $P d$ pathogenicity will fill the research gap about effector function in postharvest fungal pathogens and provide novel insights into fruit-pathogen interactions.

\subsection{Can the Revolutionary Genome Editing Biotechnology Be Used to Generate Citrus Varieties Resistant to Postharvest Green Mold?}

Despite having the citrus genome sequence and citrus genetic transformation system $[25,26]$, no other citrus gene was reported to be required for fruit resistance against $P d$ infection. Many citrus genes were proven to regulate citrus resistance to other diseases using transgenic technology [26], and whether these genes are also involved in citrus resistance to postharvest green mold remains to be investigated. Among plant defense-related genes, disease susceptibility genes (S genes), which are required for plant susceptibility to diseases and usually function as negative regulators of plant defense and targets of pathogen effectors [137], have received increased attention because disabling plant $\mathrm{S}$ genes to achieve durable and broad-spectrum resistance is a novel breeding strategy [138]. The revolutionary genome editing biotechnology has broad application prospects in plant breeding of disease resistant crops because it allows plant breeding without introducing a transgene and can produce novel plants that are similar or identical to plants generated by conventional breeding techniques $[17,139]$. Plant $S$ genes represent good targets for genome editing to create disease resistant crops; several transgene-free and disease resistant crops including tomato, cucumber, grape, and apple have been created by genome editing of plant $S$ genes including $M L O, e I F 4 E$, and DIPM via most recently, clustered regularly interspaced short palindromic repeats (CRISPR)/CRISPR-associated protein 9 (Cas9) system [140]. The CRISPR/Cas9 gene editing system has been established in citrus, and genome editing of the citrus $\mathrm{S}$ gene CSLOB1 in citrus confers resistance to citrus canker $[29,141]$. Thus, identification of citrus $S$ genes to postharvest green mold and creating resistant citrus varieties by genome editing of these citrus $S$ genes provide a promising pathway to control citrus postharvest green mold.

\section{Conclusions}

Postharvest fungal diseases on fruit have received increased attention from researchers in different fields mainly including horticulture, plant protection, and food science. Synthetic fungicides, which have noticeable health or environmental risks, are still the main method used to control them in current fruit storage. Although many nonchemical treatments, mainly including biocontrol agents, natural compounds, UV, hot water treatment, and salts have been used for controlling postharvest fungal diseases on fruit [142,143], these diseases still lead to huge economic losses worldwide every year. Increasing evidence reveals that investigating molecular mechanisms of plant-pathogen interactions is essential for developing novel and safer strategies for durably controlling plant diseases. Thus, this review focused on recent advances in the citrus fruit- $P d$ interaction, providing significant insights into fruit-pathogen interactions and is beneficial for developing novel and safer strategies for controlling citrus postharvest green mold. A total of $19 P d$ genes mainly encoding transcription factors, cell wall-related enzymes, protein kinases, and transporters are required for $P d$ pathogenicity. 
Of these $P d$ pathogenicity factors, PdChsVII and PdGcs1 are ideal targets for new drugs to control citrus postharvest green mold. Whether HIGS or SIGS of $P d$ pathogenicity factors can be used to control citrus postharvest green mold remains to be investigated. In addition, several fruit resistance responses, including ROS, NO, secondary metabolites, and primary metabolites, are involved in citrus fruit resistance against $P d$ interaction. No other citrus gene has yet been reported to regulate citrus fruit resistance. Identification and functional analysis of citrus genes that regulate citrus fruit resistance against $P d$ infection will be conducted using transgenesis or genome editing.

Funding: This study was supported by the National Natural Science Foundation of China (31972123 and 31601597), the Project of Chongqing Science and Technology Commission (cstc2018jcyjAX0654), and the Youth Top-notch Talent Support Program of Chongqing (CQYC20190525).

Conflicts of Interest: The authors declare no conflict of interest.

\section{References}

1. Liu, Y.Q.; Heying, E.; Tanumihardjo, S.A. History, global distribution, and nutritional importance of citrus fruits. Compr. Rev. Food Sci. Food Saf. 2012, 11, 530-545. [CrossRef]

2. Tian, S.; Torres, R.; Ballester, A.R.; Li, B.; Vilanova, L.; Gonzalez-Candelas, L. Molecular aspects in pathogen-fruit interactions: Virulence and resistance. Postharvest Biol. Technol. 2016, 122, 11-21. [CrossRef]

3. Wuryatmo, E.; Klieber, A.; Scott, E.S. Inhibition of citrus postharvest pathogens by vapor of citral and related compounds in culture. J. Agric. Food Chem. 2003, 51, 2637-2640. [CrossRef]

4. Macarisin, D.; Cohen, L.; Eick, A.; Rafael, G.; Belausov, E.; Wisniewski, M.; Droby, S. Penicillium digitatum suppresses production of hydrogen peroxide in host tissue during infection of citrus fruit. Phytopathology 2007, 97, 1491-1500. [CrossRef] [PubMed]

5. Marcet-Houben, M.; Ballester, A.R.; de la Fuente, B.; Harries, E.; Marcos, J.F.; Gonzalez-Candelas, L.; Gabaldon, T. Genome sequence of the necrotrophic fungus Penicillium digitatum, the main postharvest pathogen of citrus. BMC Genomics 2012, 13, 646. [CrossRef] [PubMed]

6. Hao, W.N.; Li, H.; Hu, M.Y.; Yang, L.; Rizwan-ul-Haq, M. Integrated control of citrus green and blue mold and sour rot by Bacillus amyloliquefaciens in combination with tea saponin. Postharvest Biol. Technol. 2011, 59, 316-323. [CrossRef]

7. Lopez-Perez, M.; Ballester, A.R.; Gonzalez-Candelas, L. Identification and functional analysis of Penicillium digitatum genes putatively involved in virulence towards citrus fruit. Mol. Plant Pathol. 2015, 16, $262-275$. [CrossRef]

8. Mari, M.; Di Francesco, A.; Bertolini, P. Control of fruit postharvest diseases: Old issues and innovative approaches. Stewart Postharvest Rev. 2014, 10, 1-4.

9. Mehta, A.; Brasileiro, A.C.M.; Souza, D.S.L.; Romano, E.; Campos, M.A.; Grossi-De-Sa, M.F.; Silva, M.S.; Franco, O.L.; Fragoso, R.R.; Bevitori, R.; et al. Plant-pathogen interactions: What is proteomics telling us? FEBS J. 2008, 275, 3731-3746. [CrossRef]

10. Dodds, P.N.; Rathjen, J.P. Plant immunity: Towards an integrated view of plant-pathogen interactions. Nat. Rev. Genet. 2010, 11, 539-548. [CrossRef]

11. Singh, A.; Singh, I.K. Molecular Aspects of Plant-Pathogen Interaction; Springer: Berlin/Heidelberg, Germany, 2018. [CrossRef]

12. Sang, H.; Kim, J.I. Advanced strategies to control plant pathogenic fungi by host-induced gene silencing (HIGS) and spray-induced gene silencing (SIGS). Plant Biotechnol. Rep. 2020, 14, 1-8. [CrossRef]

13. Zhang, T.; Jin, Y.; Zhao, J.H.; Gao, F.; Zhou, B.J.; Fang, Y.Y.; Guo, H.S. Host-induced gene silencing of the target gene in fungal cells confers effective resistance to the cotton wilt disease pathogen Verticillium dahliae. Mol. Plant 2016, 9, 939-942. [CrossRef] [PubMed]

14. Koch, A.; Biedenkopf, D.; Furch, A.; Weber, L.; Rossbach, O.; Abdellatef, E.; Linicus, L.; Johannsmeier, J.; Jelonek, L.; Goesmann, A.; et al. An RNAi-based control of Fusarium graminearum infections through spraying of long dsRNAs involves a plant passage and is controlled by the fungal silencing machinery. PLoS Pathog. 2016, 12, e1005901. [CrossRef] [PubMed] 
15. Saharan, V.; Jain, D.; Pareek, S.; Pal, A.; Kumaraswamy, R.V.; Jakhar, S.K.; Singh, M. Viral. Fungal and bacterial disease resistance in transgenic plants. In Advances in Plant Breeding Strategies: Agronomic, Abiotic and Biotic Stress Traits; Springer: Berlin/Heidelberg, Germany, 2016; pp. 627-656.

16. Yin, K.; Qiu, J.L. Genome editing for plant disease resistance: Applications and perspectives. Philos. T. R. Soc. B 2019, 374, 20180322. [CrossRef]

17. Langner, T.; Kamoun, S.; Belhaj, K. CRISPR crops: Plant genome editing toward disease resistance. Annu. Rev. Phytopathol. 2018, 56, 479-512. [CrossRef]

18. Wang, Y.; Cheng, X.; Shan, Q.; Zhang, Y.; Liu, J.; Gao, C.; Qiu, J.L. Simultaneous editing of three homoeoalleles in hexaploid bread wheat confers heritable resistance to powdery mildew. Nat. Biotechnol. 2014, 32, 947-951. [CrossRef]

19. Nekrasov, V.; Wang, C.; Win, J.; Lanz, C.; Weigel, D.; Kamoun, S. Rapid generation of a transgene-free powdery mildew resistant tomato by genome deletion. Sci. Rep. 2017, 7, 482. [CrossRef]

20. Dufresne, M.; Osbourn, A.E. Definition of tissue-specific and general requirements for plant infection in a phytopathogenic fungus. Mol. Plant Microbe Interact. 2001, 14, 300-307. [CrossRef]

21. Thiebaut, F.; Grativol, C.; Hemerly, A.; Ferreira, P. MicroRNA networks in plant-microorganism interactions. Trop. Plant Biol. 2015, 8, 40-50. [CrossRef]

22. Buron-Moles, G.; Lopez-Perez, M.; Gonzalez-Candelas, L.; Vinas, I.; Teixido, N.; Usall, J.; Torres, R. Use of GFP-tagged strains of Penicillium digitatum and Penicillium expansum to study host-pathogen interactions in oranges and apples. Int. J. Food Microbiol. 2012, 160, 162-170. [CrossRef]

23. Vu, T.X.; Ngo, T.T.; Mai, L.T.D.; Bui, T.T.; Le, D.H.; Bui, H.T.V.; Nguyen, H.Q.; Ngo, B.X.; Tran, V.T. A highly efficient Agrobacterium tumefaciens-mediated transformation system for the postharvest pathogen Penicillium digitatum using DsRed and GFP to visualize citrus host colonization. J. Microbiol. Meth. 2018, 144, 134-144. [CrossRef] [PubMed]

24. Costa, J.H.; Bazioli, J.M.; de Moraes Pontes, J.G.; Fill, T.P. Penicillium digitatum infection mechanisms in citrus: What do we know so far? Fungal Biol. 2019, 123, 584-593. [CrossRef] [PubMed]

25. Xu, Q.; Chen, L.L.; Ruan, X.A.; Chen, D.J.; Zhu, A.D.; Chen, C.L.; Bertrand, D.; Jiao, W.B.; Hao, B.H.; Lyon, M.P.; et al. The draft genome of sweet orange (Citrus sinensis). Nat. Genet. 2013, 45, 59. [CrossRef] [PubMed]

26. Gong, X.Q.; Liu, J.H. Genetic transformation and genes for resistance to abiotic and biotic stresses in Citrus and its related genera. Plant Cell Tiss. Org. 2013, 113, 137-147. [CrossRef]

27. Jia, H.G.; Wang, N. Targeted genome editing of sweet orange using Cas9/sgRNA. PLoS ONE 2014. [CrossRef]

28. Dutt, M.; Grosser, J.W. An embryogenic suspension cell culture system for Agrobacterium-mediated transformation of citrus. Plant Cell Rep. 2010, 29, 1251-1260. [CrossRef]

29. Jia, H.G.; Zhang, Y.Z.; Orbovic, V.; Xu, J.; White, F.F.; Jones, J.B.; Wang, N. Genome editing of the disease susceptibility gene CsLOB1 in citrus confers resistance to citrus canker. Plant Biotechnol. J. 2017, 15, 817-823. [CrossRef]

30. Perez, M.F.; Ibarreche, J.P.; Isas, A.S.; Sepulveda, M.; Ramallo, J.; Dib, J.R. Antagonistic yeasts for the biological control of Penicillium digitatum on lemons stored under export conditions. Biol. Control 2017, 115, 135-140. [CrossRef]

31. Han, Q.; Zhao, H.; Cheng, Y.; Yao, J.; Huang, L.; Kang, Z. A cytological study on infection of citrus fruits by Penicillium digitatum. Mycosystema 2013, 32, 967-977. (In Chinese)

32. Lin, Y.; Fan, L.; Xia, X.; Wang, Z.; Yin, Y.; Cheng, Y.; Li, Z. Melatonin decreases resistance to postharvest green mold on citrus fruit by scavenging defense-related reactive oxygen species. Postharvest Biol. Technol. 2019, 153, 21-30. [CrossRef]

33. Ghooshkhaneh, N.G.; Golzarian, M.R.; Mamarabadi, M. Detection and classification of citrus green mold caused by Penicillium digitatum using multispectral imaging. J. Sci. Food Agric. 2018, 98, 3542-3550. [CrossRef] [PubMed]

34. Droby, S.; Eick, A.; Macarisin, D.; Cohen, L.; Rafael, G.; Stange, R.; McColum, G.; Dudai, N.; Nasser, A.; Wisniewski, M.; et al. Role of citrus volatiles in host recognition, germination and growth of Penicillium digitatum and Penicillium italicum. Postharvest Biol. Technol. 2008, 49, 386-396. [CrossRef]

35. Pelser, P.D.T.; Eckert, J. Constituents of orange juice that stimulate the germination of conidia of Penicillium digitatum. Phytopathology 1977, 67, 747-754. [CrossRef] 
36. Plaza, P.; Usall, J.; Teixido, N.; Vinas, I. Effect of water activity and temperature on germination and growth of Penicillium digitatum, P. italicum and Geotrichum candidum. J. Appl. Microbiol. 2003, 94, 549-554. [CrossRef]

37. Hocking, A.D.; Pitt, J. Water relations of some Penicillium species at 25 C. Trans. Br. Mycol. Soc. 1979, 73, 141-145. [CrossRef]

38. Araujo, E.D.; Vendramini, P.H.; Costa, J.H.; Eberlin, M.N.; Montagner, C.C.; Fill, T.P. Determination of tryptoquialanines A and C produced by Penicillium digitatum in oranges: Are we safe? Food Chem. 2019, 301, 125285. [CrossRef]

39. Costa, J.H.; Bazioli, J.M.; Araujo, E.D.; Vendramini, P.H.; Porto, C.M.C.D.; Eberlin, M.N.; Souza-Neto, J.A.; Fill, T.P. Monitoring indole alkaloid production by Penicillium digitatum during infection process in citrus by Mass Spectrometry Imaging and molecular networking. Fungal Biol. 2019, 123, 594-600. [CrossRef]

40. Ariza, M.R.; Larsen, T.O.; Petersen, B.O.; Duus, J.O.; Barrero, A.F. Penicillium digitatum metabolites on synthetic media and citrus fruits. J. Agric. Food Chem. 2002, 50, 6361-6365. [CrossRef]

41. Adam, G.; Wiesenberger, G.; Güldener, U. Fusarium mycotoxins and their role in plant-pathogen interactions. In Biosynthesis and Molecular Genetics of Fungal Secondary Metabolites; Springer: Berlin/Heidelberg, Germany, 2015; Volume 2, pp. 199-233.

42. Sánchez-Rangel, D.; Plasencia, J. The role of sphinganine analog mycotoxins on the virulence of plant pathogenic fungi. Toxin Rev. 2010, 29, 73-86. [CrossRef]

43. Sanzani, S.M.; Reverberi, M.; Punelli, M.; Ippolito, A.; Fanelli, C. Study on the role of patulin on pathogenicity and virulence of Penicillium expansum. Int. J. Food Microbiol. 2012, 153, 323-331. [CrossRef]

44. Zhu, C.; Sheng, D.; Wu, X.; Wang, M.; Hu, X.; Li, H.; Yu, D. Identification of secondary metabolite biosynthetic gene clusters associated with the infection of citrus fruit by Penicillium digitatum. Postharvest Biol. Technol. 2017, 134, 17-21. [CrossRef]

45. Julca, I.; Droby, S.; Sela, N.; Marcet-Houben, M.; Gabaldon, T. Contrasting genomic diversity in two closely related postharvest pathogens: Penicillium digitatum and Penicillium expansum. Genome Biol. Evol. 2016, 8, 218-227. [CrossRef] [PubMed]

46. Zhang, W.Q.; Gui, Y.J.; Short, D.P.G.; Li, T.G.; Zhang, D.D.; Zhou, L.; Liu, C.; Bao, Y.M.; Subbarao, K.V.; Chen, J.Y.; et al. Verticillium dahliae transcription factor VdFTF1 regulates the expression of multiple secreted virulence factors and is required for full virulence in cotton. Mol. Plant Pathol. 2018, 19, 841-857. [CrossRef]

47. Rispail, N.; Di Pietro, A. The homeodomain transcription factor Ste12: Connecting fungal MAPK signaling to plant pathogenicity. Commun. Integr. Biol. 2010, 3, 327-332.

48. Vilanova, L.; Teixido, N.; Torres, R.; Usall, J.; Vinas, I.; Sanchez-Torres, P. Relevance of the transcription factor PdSte12 in Penicillium digitatum conidiation and virulence during citrus fruit infection. Int. J. Food Microbiol. 2016, 235, 93-102. [CrossRef] [PubMed]

49. De Ramón-Carbonell, M.; Sánchez-Torres, P. The transcription factor PdSte12 contributes to Penicillium digitatum virulence during citrus fruit infection. Postharvest Biol. Technol. 2017, 125, 129-139. [CrossRef]

50. Sun, X.; Wang, J.; Feng, D.; Ma, Z.; Li, H. PdCYP51B, a new putative sterol $14 \alpha$-demethylase gene of Penicillium digitatum involved in resistance to imazalil and other fungicides inhibiting ergosterol synthesis. Appl. Microbiol. Biot. 2011, 91, 1107. [CrossRef]

51. Penalva, M.A.; Tilburn, J.; Bignell, E.; Arst, H.N. Ambient pH gene regulation in fungi: Making connections. Trends Microbiol. 2008, 16, 291-300. [CrossRef]

52. Prusky, D.; McEvoy, J.L.; Saftner, R.; Conway, W.S.; Jones, R. Relationship between host acidification and virulence of Penicillium spp. on apple and citrus fruit. Phytopathology 2004, 94, 44-51. [CrossRef]

53. Zhang, T.Y.; Sun, X.P.; Xu, Q.; Candelas, L.G.; Li, H.Y. The pH signaling transcription factor PacC is required for full virulence in Penicillium digitatum. Appl. Microbiol. Biot. 2013, 97, 9087-9098. [CrossRef]

54. Tisi, R.; Rigamonti, M.; Groppi, S.; Belotti, F. Calcium homeostasis and signaling in fungi and their relevance for pathogenicity of yeasts and filamentous fungi. AIMS Mol. Sci. 2016. [CrossRef]

55. Soriani, F.M.; Malavazi, I.; Ferreira, M.E.D.; Savoldi, M.; Kress, M.R.V.; Goldman, M.H.D.; Loss, O.; Bignell, E.; Goldman, G.H. Functional characterization of the Aspergillus fumigatus CRZ1 homologue, CrzA. Mol. Microbiol. 2008, 67, 1274-1291. [CrossRef] [PubMed]

56. Schumacher, J.; de Larrinoa, I.F.; Tudzynski, B. Calcineurin-responsive zinc finger transcription factor CRZ1 of Botrytis cinerea is required for growth, development, and full virulence on bean plants. Eukaryot. Cell 2008, 7, 584-601. [CrossRef] [PubMed] 
57. Zhang, H.F.; Zhao, Q.; Liu, K.Y.; Zhang, Z.G.; Wang, Y.C.; Zheng, X.B. MgCRZ1, a transcription factor of Magnaporthe grisea, controls growth, development and is involved in full virulence. FEMS Microbiol. Lett. 2009, 293, 160-169. [CrossRef]

58. Zhang, T.Y.; Xu, Q.; Sun, X.P.; Li, H.Y. The calcineurin-responsive transcription factor Crz1 is required for conidation, full virulence and DMI resistance in Penicillium digitatum. Microbiol. Res. 2013, 168, 211-222. [CrossRef]

59. Espenshade, P.J.; Hughes, A.L. Regulation of sterol synthesis in eukaryotes. Annu. Rev. Genet. 2007, 41, 401-427. [CrossRef]

60. Bien, C.M.; Espenshade, P.J. Sterol regulatory element binding proteins in fungi: Hypoxic transcription factors linked to pathogenesis. Eukaryot. Cell 2010, 9, 352-359. [CrossRef]

61. Liu, J.; Yuan, Y.; Wu, Z.; Li, N.; Chen, Y.; Qin, T.; Geng, H.; Xiong, L.; Liu, D. A novel sterol regulatory element-binding protein gene (sreA) identified in Penicillium digitatum is required for prochloraz resistance, full virulence and erg11 (cyp51) regulation. PLoS ONE 2015, 10, e0117115. [CrossRef]

62. Ruan, R.; Wang, M.; Liu, X.; Sun, X.; Chung, K.R.; Li, H. Functional analysis of two sterol regulatory element binding proteins in Penicillium digitatum. PLoS ONE 2017, 12, e0176485. [CrossRef]

63. Lenardon, M.D.; Munro, C.A.; Gow, N.A.R. Chitin synthesis and fungal pathogenesis. Curr. Opin. Microbiol. 2010, 13, 416-423. [CrossRef]

64. Cantarel, B.L.; Coutinho, P.M.; Rancurel, C.; Bernard, T.; Lombard, V.; Henrissat, B. The Carbohydrate-Active EnZymes database (CAZy): An expert resource for Glycogenomics. Nucleic Acids Res. 2009, 37, D233-D238. [CrossRef] [PubMed]

65. Lyu, X.L.; Shen, C.C.; Fu, Y.P.; Xie, J.T.; Jiang, D.H.; Li, G.Q.; Cheng, J.S. Comparative genomic and transcriptional analyses of the carbohydrate-active enzymes and secretomes of phytopathogenic fungi reveal their significant roles during infection and development. Sci. Rep. 2015, 5, 15565. [CrossRef] [PubMed]

66. Vilanova, L.; Lopez-Perez, M.; Ballester, A.R.; Teixido, N.; Usall, J.; Lara, I.; Vinas, I.; Torres, R.; Gonzalez-Candelas, L. Differential contribution of the two major polygalacturonases from Penicillium digitatum to virulence towards citrus fruit. Int. J. Food Microbiol. 2018, 282, 16-23. [CrossRef] [PubMed]

67. Ramoni, J.; Seiboth, B. Degradation of plant cell wall polymers by fungi. In Environmental and Microbial Relationships; Springer: Berlin/Heidelberg, Germany, 2016; pp. 127-148.

68. Gandia, M.; Harries, E.; Marcos, J.F. Identification and characterization of chitin synthase genes in the postharvest citrus fruit pathogen Penicillium digitatum. Fungal Biol. 2012, 116, 654-664. [CrossRef]

69. Gandia, M.; Harries, E.; Marcos, J.F. The myosin motor domain-containing chitin synthase PdChsVII is required for development, cell wall integrity and virulence in the citrus postharvest pathogen Penicillium digitatum. Fungal Genet. Biol. 2014, 67, 58-70. [CrossRef]

70. Harries, E.; Gandia, M.; Carmona, L.; Marcos, J.F. The Penicillium digitatum protein O-mannosyltransferase Pmt2 is required for cell wall integrity, conidiogenesis, virulence and sensitivity to the antifungal peptide PAF26. Mol. Plant Pathol. 2015, 16, 748-761. [CrossRef] [PubMed]

71. Merzendorfer, $\mathrm{H}$. The cellular basis of chitin synthesis in fungi and insects: Common principles and differences. Eur. J. Cell Biol. 2011, 90, 759-769. [CrossRef]

72. Oka, T.; Hamaguchi, T.; Sameshima, Y.; Goto, M.; Furukawa, K. Molecular characterization of protein O-mannosyltransferase and its involvement in cell-wall synthesis in Aspergillus nidulans. Microbiology 2004, 150, 1973-1982. [CrossRef]

73. Turra, D.; Segorbe, D.; Di Pietro, A. Protein kinases in plant-pathogenic fungi: Conserved regulators of infection. Annu. Rev. Phytopathol. 2014, 52, 267-288. [CrossRef]

74. Zhao, X.H.; Mehrabi, R.; Xu, J.R. Mitogen-activated protein kinase pathways and fungal pathogenesis. Eukaryot. Cell 2007, 6, 1701-1714. [CrossRef]

75. Ma, H.J.; Sun, X.P.; Wang, M.S.; Gai, Y.P.; Chung, K.R.; Li, H.Y. The citrus postharvest pathogen Penicillium digitatum depends on the PdMpkB kinase for developmental and virulence functions. Int. J. Food Microbiol. 2016, 236, 167-176. [CrossRef] [PubMed]

76. De Ramón-Carbonell, M.; Sánchez-Torres, P. PdSlt2 Penicillium digitatum mitogen-activated-protein kinase controls sporulation and virulence during citrus fruit infection. Fungal Biol. 2017, 121, 1063-1074. [CrossRef] [PubMed] 
77. Wang, M.; Chen, C.; Zhu, C.; Sun, X.; Ruan, R.; Li, H. Os2 MAP kinase-mediated osmostress tolerance in Penicillium digitatum is associated with its positive regulation on glycerol synthesis and negative regulation on ergosterol synthesis. Microbiol. Res. 2014, 169, 511-521. [CrossRef] [PubMed]

78. Zhang, T.Y.; Sun, X.P.; Xu, Q.; Zhu, C.Y.; Li, Q.Z.; Li, H.Y. PdSNF1, a sucrose non-fermenting protein kinase gene, is required for Penicillium digitatum conidiation and virulence. Appl. Microbiol. Biot. 2013, 97, 5433-5445. [CrossRef]

79. De Waard, M.A.; Andrade, A.C.; Hayashi, K.; Schoonbeek, H.J.; Stergiopoulos, I.; Zwiers, L.H. Impact of fungal drug transporters on fungicide sensitivity, multidrug resistance and virulence. Pest Manag. Sci. 2006, 62, 195-207. [CrossRef]

80. Wang, J.Y.; Sun, X.P.; Lin, L.Y.; Zhang, T.Y.; Ma, Z.H.; Li, H.Y. PdMfs1, a major facilitator superfamily transporter from Penicillium digitatum, is partially involved in the imazalil-resistance and pathogenicity. Afr. J. Microbiol. Res. 2012, 6, 95-105.

81. Wu, Z.; Wang, S.Q.; Yuan, Y.Z.; Zhang, T.F.; Liu, J.; Liu, D.L. A novel major facilitator superfamily transporter in Penicillium digitatum (PdMFS2) is required for prochloraz resistance, conidiation and full virulence. Biotechnol. Lett. 2016, 38, 1349-1357. [CrossRef]

82. Nakaune, R.; Adachi, K.; Nawata, O.; Tomiyama, M.; Akutsu, K.; Hibi, T. A novel ATP-binding cassette transporter involved in multidrug resistance in the phytopathogenic fungus Penicillium digitatum. Appl. Environ. Microb. 1998, 64, 3983-3988. [CrossRef]

83. Nakaune, R.; Hamamoto, H.; Imada, J.; Akutsu, K.; Hibi, T. A novel ABC transporter gene, PMR5, is involved in multidrug resistance in the phytopathogenic fungus Penicillium digitatum. Mol. Genet. Genomics 2002, 267, 179-185. [CrossRef]

84. Hamamoto, H.; Nawata, O.; Hasegawa, K.; Nakaune, R.; Lee, Y.J.; Makizumi, Y.; Akutsu, K.; Hibi, T. The role of the ABC transporter gene PMR1 in demethylation inhibitor resistance in Penicillium digitatum. Pestic Biochem. Phys. 2001, 70, 19-26. [CrossRef]

85. Callahan, T.M.; Rose, M.S.; Meade, M.J.; Ehrenshaft, M.; Upchurch, R.G. CFP, the putative cercosporin transporter of Cercospora kikuchii, is required for wild type cercosporin production, resistance, and virulence on soybean. Mol. Plant Microbe. Interact. 1999, 12, 901-910. [CrossRef] [PubMed]

86. Choquer, M.; Lee, M.H.; Bau, H.J.; Chung, K.R. Deletion of a MFS transporter-like gene in Cercospora nicotianae reduces cercosporin toxin accumulation and fungal virulence. FEMS Lett. 2007, 581, 489-494.

87. Pitkin, J.W.; Panaccione, D.G.; Walton, J.D. A putative cyclic peptide efflux pump encoded by the TOXA gene of the plant-pathogenic fungus Cochliobolus carbonum. Microbiology 1996, 142, 1557-1565. [CrossRef] [PubMed]

88. De Ramon-Carbonell, M.; Sanchez-Torres, P. Involvement of Penicillium digitatum PdSUT1 in fungicide sensitivity and virulence during citrus fruit infection. Microbiol. Res. 2017, 203, 57-67. [CrossRef] [PubMed]

89. Reinders, A.; Ward, J.M. Functional characterization of the $\alpha$-glucoside transporter Sut1p from Schizosaccharomyces pombe, the first fungal homologue of plant sucrose transporters. Mol. Microbiol. 2001, 39, 445-455. [CrossRef] [PubMed]

90. Cheng, Y.; Lin, Y.; Cao, H.; Yao, J.; Li, Z. Ubiquitylome study highlights ubiquitination of primary metabolism related proteins in fruit response to postharvest pathogen infection. Postharvest Biol. Technol. 2020, 163, 11142. [CrossRef]

91. Zhu, C.; Wang, M.; Wang, W.; Ruan, R.; Ma, H.; Mao, C.; Li, H. Glucosylceramides are required for mycelial growth and full virulence in Penicillium digitatum. Biochem. Biophys. Res. Commun. 2014, 455, 165-171. [CrossRef]

92. Del Poeta, M.; Nimrichter, L.; Rodrigues, M.L.; Luberto, C. Synthesis and biological properties of fungal glucosylceramide. PLoS Pathog. 2014, 10, e1003832. [CrossRef]

93. De Coninck, B.; Verheesen, P.; Vos, C.M.; Van Daele, I.; De Bolle, M.F.; Vieira, J.V.; Peferoen, M.; Cammue, B.P.A.; Thevissen, K. Fungal glucosylceramide-specific camelid single domain antibodies are characterized by broad spectrum antifungal activity. Front. Microbiol. 2017, 8, 1059. [CrossRef]

94. Daniel, P.B.; Walker, W.H.; Habener, J.F. Cyclic AMP signaling and gene regulation. Annu. Rev. Nutr. 1998, 18, 353-383. [CrossRef]

95. Wang, W.; Wang, M.; Wang, J.; Zhu, C.; Chung, K.-R.; Li, H. Adenylyl cyclase is required for cAMP production, growth, conidial germination, and virulence in the citrus green mold pathogen Penicillium digitatum. Microbiol. Res. 2016, 192, 11-20. [CrossRef] [PubMed] 
96. Zhang, J.; Li, L.; Lv, Q.; Yan, L.; Wang, Y.; Jiang, Y. The fungal CYP51s: Their functions, structures, related drug resistance, and inhibitors. Front. Microbiol. 2019, 10, 691. [CrossRef] [PubMed]

97. de Ramón-Carbonell, M.; Sánchez-Torres, P. Significance of 195 bp-enhancer of PdCYP51B in the acquisition of Penicillium digitatum DMI resistance and increase of fungal virulence. Pestic. Biochem. Phys. 2020. Available online: https://doi.org/10.1016/j.pestbp.2020.01.003 (accessed on 10 March 2020).

98. Louw, J.P.; Korsten, L. Pathogenicity and host susceptibility of Penicillium spp. on Citrus. Plant Dis. 2015, 99, 21-30. [CrossRef]

99. Vilanova, L.; Vinas, I.; Torres, R.; Usall, J.; Buron-Moles, G.; Teixido, N. Acidification of apple and orange hosts by Penicillium digitatum and Penicillium expansum. Int. J. Food Microbiol. 2014, 178, 39-49. [CrossRef] [PubMed]

100. Scheler, C.; Durner, J.; Astier, J. Nitric oxide and reactive oxygen species in plant biotic interactions. Curr. Opin. Plant Biol. 2013, 16, 534-539. [CrossRef]

101. Torres, M.A.; Jones, J.D.; Dangl, J.L. Reactive oxygen species signaling in response to pathogens. Plant Physiol. 2006, 141, 373-378. [CrossRef]

102. Yun, B.W.; Skelly, M.J.; Yin, M.H.; Yu, M.D.; Mun, B.G.; Lee, S.U.; Hussain, A.; Spoel, S.H.; Loake, G.J. Nitric oxide and S-nitrosoglutathione function additively during plant immunity. New Phytol. 2016, 211, 516-526. [CrossRef]

103. Romero-Puertas, M.C.; Perazzolli, M.; Zago, E.D.; Delledonne, M. Nitric oxide signalling functions in plant-pathogen interactions. Cell. Microbiol. 2004, 6, 795-803. [CrossRef]

104. Yu, M.D.; Lamattina, L.; Spoel, S.H.; Loake, G.J. Nitric oxide function in plant biology: A redox cue in deconvolution. New Phytol. 2014, 202, 1142-1156. [CrossRef]

105. Zhou, Y.H.; Li, S.M.; Zeng, K.F. Exogenous nitric oxide-induced postharvest disease resistance in citrus fruit to Colletotrichum gloeosporioides. J. Sci. Food Agric. 2016, 96, 505-512. [CrossRef] [PubMed]

106. Li, G.J.; Zhu, S.H.; Wu, W.X.; Zhang, C.; Peng, Y.; Wang, Q.G.; Shi, J.Y. Exogenous nitric oxide induces disease resistance against Monilinia fructicola through activating the phenylpropanoid pathway in peach fruit. J. Sci. Food Agric. 2017, 97, 3030-3038. [CrossRef] [PubMed]

107. Fan, B.; Shen, L.; Liu, K.L.; Zhao, D.Y.; Yu, M.M.; Sheng, J.P. Interaction between nitric oxide and hydrogen peroxide in postharvest tomato resistance response to Rhizopus nigricans. J. Sci. Food Agric. 2008, 88, 1238-1244. [CrossRef]

108. Zheng, Y.; Hong, H.; Chen, L.; Li, J.; Sheng, J.; Shen, L. LeMAPK1, LeMAPK2, and LeMAPK3 are associated with nitric oxide-induced defense response against Botrytis cinerea in the Lycopersicon esculentum fruit. J. Agric. Food Chem. 2014, 62, 1390-1396. [CrossRef] [PubMed]

109. Zheng, Y.; Sheng, J.; Zhao, R.; Zhang, J.; Lv, S.; Liu, L.; Shen, L. Preharvest L-arginine treatment induced postharvest disease resistance to Botrysis cinerea in tomato fruits. J. Agric. Food Chem. 2011, 59, 6543-6549. [CrossRef] [PubMed]

110. Wang, M.M.; Yu, J.; Zhong, Y.; Jiang, B.; Wu, B.; Yan, H.X. Expression analysis of the MAPK genes in exogenous NO induced disease resistance to Penicillium digitatum in the postharvest citrus fruits. Guangdong Agric. Sci. 2018, 45, 11. (In Chinese)

111. Wink, M. Plant secondary metabolism: Diversity, function and its evolution. Nat. Prod. Commun. 2008, 3, 1205-1216. [CrossRef]

112. Ballester, A.R.; Lafuente, M.T.; Gonzalez-Candelas, L. Citrus phenylpropanoids and defence against pathogens. Part II: Gene expression and metabolite accumulation in the response of fruits to Penicillium digitatum infection. Food Chem. 2013, 136, 285-291. [CrossRef]

113. Gonzalez-Candelas, L.; Alamar, S.; Sanchez-Torres, P.; Zacarias, L.; Marcos, J.F. A transcriptomic approach highlights induction of secondary metabolism in citrus fruit in response to Penicillium digitatum infection. BMC Plant Biol. 2010, 10, 194. [CrossRef]

114. La Camera, S.; Gouzerh, G.; Dhondt, S.; Hoffmann, L.; Fritig, B.; Legrand, M.; Heitz, T. Metabolic reprogramming in plant innate immunity: The contributions of phenylpropanoid and oxylipin pathways. Immunol. Rev. 2004, 198, 267-284. [CrossRef]

115. Ballester, A.R.; Lafuente, M.T.; de Vos, R.C.H.; Bovy, A.G.; Gonzalez-Candelas, L. Citrus phenylpropanoids and defence against pathogens. Part I: Metabolic profiling in elicited fruits. Food Chem. 2013, 136, 178-185. [CrossRef] [PubMed] 
116. Bolton, M.D. Primary metabolism and plant defense-fuel for the fire. Mol. Plant Microbe. Interact. 2009, 22, 487-497. [CrossRef] [PubMed]

117. Rojas, C.M.; Senthil-Kumar, M.; Tzin, V.; Mysore, K.S. Regulation of primary plant metabolism during plant-pathogen interactions and its contribution to plant defense. Front. Plant Sci. 2014, 5, 17. [CrossRef] [PubMed]

118. Less, H.; Angelovici, R.; Tzin, V.; Galili, G. Coordinated gene networks regulating Arabidopsis plant metabolism in response to various stresses and nutritional cues. Plant Cell 2011, 23, 1264-1271. [CrossRef] [PubMed]

119. Herbers, K.; Meuwly, P.; Métraux, J.P.; Sonnewald, U. Salicylic acid-independent induction of pathogenesis-related protein transcripts by sugars is dependent on leaf developmental stage. FEBS Lett. 1996, 397, 239-244. [CrossRef]

120. Yi, C.; Qu, H.X.; Jiang, Y.M.; Shi, J.; Duan, X.W.; Joyce, D.C.; Li, Y.B. ATP-induced changes in energy status and membrane integrity of harvested litchi fruit and its relation to pathogen resistance. J. Phytopathol. 2008, 156, 365-371. [CrossRef]

121. Yun, Z.; Gao, H.J.; Liu, P.; Liu, S.Z.; Luo, T.; Jin, S.; Xu, Q.; Xu, J.; Cheng, Y.J.; Deng, X.X. Comparative proteomic and metabolomic profiling of citrus fruit with enhancement of disease resistance by postharvest heat treatment. BMC Plant Biol. 2013, 13, 44. [CrossRef]

122. Frisvad, J.C.; Samson, R.A. Polyphasic taxonomy of Penicillium subgenus Penicillium-A guide to identification of food and air-borne terverticillate Penicillia and their mycotoxins. Stud. Mycol. 2004, $49,1-74$.

123. Stange, R.R.; Midland, S.L.; Sims, J.J.; McCollum, T.G. Differential effects of citrus peel extracts on growth of Penicillium digitatum, P. italicum, and P. expansum. Physiol. Mol. Plant Pathol. 2002, 61, 303-311. [CrossRef]

124. Louw, J.P.; Korsten, L. Postharvest decay of nectarine and plum caused by Penicillium spp. Eur. J. Plant Pathol. 2016, 146, 779-791. [CrossRef]

125. Louw, J.P.; Korsten, L. Pathogenic Penicillium spp. on apple and pear. Plant Dis. 2014, 98, 590-598. [CrossRef] [PubMed]

126. Vilanova, L.; Vinas, I.; Torres, R.; Usall, J.; Buron-Moles, G.; Teixido, N. Increasing maturity reduces wound response and lignification processes against Penicillium expansum (pathogen) and Penicillium digitatum (non-host pathogen) infection in apples. Postharvest Biol. Technol. 2014, 88, 54-60. [CrossRef]

127. Louw, J.P.; Korsten, L. Impact of postharvest storage on the infection and colonization of Penicillium digitatum and Penicillium expansum on nectarine. Plant Dis. 2019, 103, 1584-1594. [CrossRef] [PubMed]

128. Louw, J.P.; Korsten, L. Impact of ripeness on the infection and colonisation of Penicillium digitatum and P. expansum on plum. Postharvest Biol. Technol. 2019, 149, 148-158. [CrossRef]

129. Buron-Moles, G.; Torres, R.; Teixido, N.; Usall, J.; Vilanova, L.; Vinas, I. Characterisation of $\mathrm{H}_{2} \mathrm{O}_{2}$ production to study compatible and non-host pathogen interactions in orange and apple fruit at different maturity stages. Postharvest Biol. Technol. 2015, 99, 27-36. [CrossRef]

130. Vilanova, L.; Wisniewski, M.; Norelli, J.; Vinas, I.; Torres, R.; Usall, J.; Phillips, J.; Droby, S.; Teixido, N. Transcriptomic profiling of apple in response to inoculation with a pathogen (Penicillium expansum) and a non-pathogen (Penicillium digitatum). Plant Mol. Biol. Rep. 2014, 32, 566-583. [CrossRef]

131. Buron-Moles, G.; Wisniewski, M.; Vinas, I.; Teixido, N.; Usall, J.; Droby, S.; Torres, R. Characterizing the proteome and oxi-proteome of apple in response to a host (Penicillium expansum) and a non-host (Penicillium digitatum) pathogen. J. Proteomics 2015, 114, 136-151. [CrossRef]

132. Cheng, Y.; Wu, K.; Yao, J.; Li, S.; Wang, X.; Huang, L.; Kang, Z. PST ha5a23, a candidate effector from the obligate biotrophic pathogen Puccinia striiformis f. sp. tritici, is involved in plant defense suppression and rust pathogenicity. Environ. Microbiol. 2017, 19, 1717-1729.

133. Varden, F.A.; De la Concepcion, J.C.; Maidment, J.H.; Banfield, M.J. Taking the stage: Effectors in the spotlight. Curr. Opin. Plant Biol. 2017, 38, 25-33. [CrossRef]

134. Giraldo, M.C.; Valent, B. Filamentous plant pathogen effectors in action. Nat. Rev. Microbiol. 2013, 11, 800-814. [CrossRef]

135. Van de Wouw, A.P.; Idnurm, A. Biotechnological potential of engineering pathogen effector proteins for use in plant disease management. Biotechnol. Adv. 2019, 37, 107387. [CrossRef] [PubMed] 
136. Qi, T.; Guo, J.; Liu, P.; He, F.; Wan, C.; Islam, M.A.; Tyler, B.M.; Kang, Z.; Guo, J. Stripe rust effector PstGSRE1 disrupts nuclear localization of ROS-promoting transcription factor TaLOL2 to defeat ROS-induced defense in wheat. Mol. Plant. 2019, 12, 1624-1638. [CrossRef] [PubMed]

137. Gawehns, F.; Cornelissen, B.J.; Takken, F.L. The potential of effector-target genes in breeding for plant innate immunity. Microb. Biotechnol. 2013, 6, 223-229. [CrossRef] [PubMed]

138. Pavan, S.; Jacobsen, E.; Visser, R.G.; Bai, Y. Loss of susceptibility as a novel breeding strategy for durable and broad-spectrum resistance. Mol. Breeding 2010, 25, 1. [CrossRef]

139. Araki, M.; Ishii, T. Towards social acceptance of plant breeding by genome editing. Trends Plant Sci. 2015, 20, 145-149. [CrossRef]

140. Zaidi, S.S.E.A.; Mukhtar, M.S.; Mansoor, S. Genome editing: Targeting susceptibility genes for plant disease resistance. Trends Biotechnol. 2018, 36, 898-906. [CrossRef]

141. Peng, A.; Chen, S.; Lei, T.; Xu, L.; He, Y.; Wu, L.; Yao, L.; Zou, X. Engineering canker-resistant plants through CRISPR/Cas9-targeted editing of the susceptibility gene CsLOB1 promoter in citrus. Plant Biotechnol. J. 2017, 15, 1509-1519. [CrossRef]

142. Di Francesco, A.; Martini, C.; Mari, M. Biological control of postharvest diseases by microbial antagonists: How many mechanisms of action? Eur. J. Plant Pathol. 2016, 145, 711-717. [CrossRef]

143. Papoutsis, K.; Mathioudakis, M.M.; Hasperué, J.H.; Ziogas, V. Non-chemical treatments for preventing the postharvest fungal rotting of citrus caused by Penicillium digitatum (green mold) and Penicillium italicum (blue mold). Trends Food Sci. Technol. 2019, 86, 479-491. [CrossRef]

(C) 2020 by the authors. Licensee MDPI, Basel, Switzerland. This article is an open access article distributed under the terms and conditions of the Creative Commons Attribution (CC BY) license (http://creativecommons.org/licenses/by/4.0/). 